\title{
EXPRESSION OF $\alpha$-SMA, DESMIN AND VIMENTIN IN CANINE LIVER WITH FIBROSIS
}

KNEŽEVIĆ MILIJANA*, GLEDIĆ D*, KUKOLJ V*, KNEŽEVIĆ DJ**, JOVANOVIĆ M*, BOŽIĆ TATJANA* and ALEKSIĆ-KOVAČEVIĆ SANJA*

*University of Belgrade, Faculty of Veterinary Medicine, Belgrade, Serbia **Institute of Digestive Diseases, Clinical Center of Serbia, Belgrade, Serbia

(Received 13 $3^{\text {th }}$ March 2008)

In this work, 36 canine livers with fibrosis were examined. Based on the degree of fibrosis, the livers were classified into three groups: 1mild portal fibrosis; 2- moderate portal fibrosis with mild periportal and septal fibrosis; 3- severe portal fibrosis with marked periportal and septal fibrosis or cirrhosis. Normal liver sections obtained from five dogs with no evidence of infectious, neoplastic, or cardiovascular diseases were used as controls. The degree of fibrosis was evaluated on liver sections stained according to Masson's trichrome method. It was proved using an immunohistochemical method that HSC and periductal myofibroblasts are immunoreactive to desmin, vimentin and $\alpha-S M A$. Desmin, vimentin and $\alpha-S M A$ positive cells in the portal triad were significantly more numerous in dogs with fibrosis of the third degree than in the controls or all other examined livers. The density of $\alpha-$ SMA, vimentin and desmin-positive cells in the portal triad was in correlation with the degree of fibrosis, which cannot be said for HSC. These results suggest that portal myofibroblasts have a significant role in the process of liver fibrosis in dogs.

Key words: dogs, HSC, immunohistochemistry, liver fibrosis, myofibroblasts

\section{INTRODUCTION}

The etiopathogenesis of chronic liver diseases in dogs, including fibrosis and cirrhosis, has not been sufficiently clarified so far. Canine hepatic fibrosis develops after damage is incurred to parenchymatous cells by infective agents, toxins, medicines, chemicals, malnutrition, metabolites, and hypoxia (Bataller and Brenner, 2005; Watson, 2004; Center, 1999; Adamus et al., 1997). Hepatocyte damage is usually present several months before the accumulation of scar tissue. Hepatic stellate cells (HSC) in humans and rats are doubtlessly the most significant cells that are engaged in the synthesis of the extracellular matrix that is present in liver fibrosis (Moreira, 2007; Guyot et al., 2006; Senoo, 2004; Bedossa and Paradis, 2003; Reeves and Friedman, 2002; Safadi and Friedman, 2002; Lepreux et al., 2001; Friedman, 2000; Knittel et al., 1999a,b; Hautekeete and 
Geerts, 1997). As a consequence of liver damage, HSC are activated, and they are transformed from inactive, dormant cells, to myofibroblast-like cells with new phenotype characteristics. The HSC, which are traditionally considered as cells of mesenchymal origin, express molecules of vimentin, desmin, and $\alpha$-SMA. Some investigations have shown that these cells in certain biological species also express a glial fibrillar acidic protein, nestin, a receptor for neurotrophin and synaptophysin with important differences between species (Zhao and Burt, 2007; Cassiman et al., 2002). In the process of development of fibrosis, the loss of hepatocytes leads to the activation of portal myofibroblasts as well, which in dogs have doubtlessly greater importance in the fibrogenesis process than HSC (Hinz et al., 2007; Mekonnen et al., 2007; ljzer et al., 2006; Boisclair et al., 2001; Burt, 1999). Periductal myofibroblasts express laminin, tenascin, type-IV collagen, elastin and fibrillin (Ramadori and Saile, 2004; Sato et al., 2003; Tuchweber et al., 1996). Initial histological changes in the course of development of portal fibrosis imply the accumulation of inflammation cells and matrix proteins around the portal vein. This form of fibrosis occurs most frequently as a consequence of viral hepatitis. On the other hand, biliary fibrosis develops as a consequence following the obstruction of biliary pathways and it is characterized morphologically by rapid activation of fibroblasts and accumulation of collagen in the portal and periportal regions of the liver. In addition, oedema develops and a proliferation of the bile ducts. Fibrosis which spreads from one portal region to another or toward the centrolobular parts of the liver is marked as bridging fibrosis and it damages the function of the liver more seriously than other forms of fibrosis. Furthermore, liver fibrosis can be manifested in the form of focal, multifocal, and diffuse fibrosis (Ramadori and Saile, 2004; Cassiman et al., 2002). Based on the presence of fibrotic fields (pathological niche), liver fibrosis is classified into three categories (Mekonnen et al., 2007; Ide et al., 2001; Boisclair et al., 2001; Yamate et al., 1996).

In this paper we have described the distribution and localization of cells that express $\alpha$-SMA, desmin and vimentin in the liver of dogs with various degrees of fibrosis, as well as the significance of HSC and portal myofibroblasts in the genesis of fibrosis.

\section{MATERIAL AND METHODS}

The material examined in this work were liver samples of dogs on which autopsies were peformed at the Department of Pathology of the Faculty of Veterinary Medicine of the University of Belgrade during the period from 19962006. A total of 36 dogs of different breeds, gender, and age were examined. The histological criteria for the selection of the examined samples were defined on the basis of the suggestion of the International Association of the Study of the Liver and the World Congress of Gastroenterology (Boisclair et al., 2001). Based on the degree of fibrosis, the livers were classified into three groups: 1- mild portal fibrosis; 2- moderate portal fibrosis with mild periportal and septal fibrosis; 3severe portal fibrosis with marked periportal and septal fibrosis or cirrhosis. Normal liver sections obtained from five dogs without evidence of infectious, neoplastic, or cardiac disease were used as controls. 
All liver samples for pathohistological and immunohistochemical studies were fixed in $10 \%$ buffered formalin, and after standard processing in an automated tissue processor, cast in paraffin blocks. The paraffin sections 3-5 $\mu \mathrm{m}$ thick were stained with hematoxylin and eosin (HE) and with Masson's trichrome for light microscopic examination.

Immunohistochemical procedure: A three-step indirect immunohistochemical technique was performed on $4 \mu \mathrm{m}$ formalin-fixed and paraffin embedded sections. Antigen retrieval was achieved by cooking the sections in a microwave oven at $560 \mathrm{~W}$ for 21 minutes in citrate buffer ( $\mathrm{pH}$ 6.0). The sections were then treated with methanol containing $0.3 \%$ hydrogen peroxide for 15 minutes at room temperature in order to inactivate endogenous peroxidase. Nonspecific binding of secondary antibodies was minimized by incubating with $50 \%$ normal goat serum in PBS for 20 minutes. Sections were incubated with appropriate primary antibodies (Table 1) diluted in PBS for 1 hour in a humid chamber at room temperature. All rinsing procedures and serum dilutions were done in PBS ( $\mathrm{pH}$ 7.2-7.4). The detection kit was DAKO Cytomation LSAB2 System-HRP, Rabbit/mouse (DAKO, K0675). Positive reactions were visualized by applying $\mathrm{DAB}+(\mathrm{DAKO}, \mathrm{K} 3468)$ for 5 to 10 minutes. Counterstaining with HE was done for 2 seconds. Aqueous medium glycergel (DAKO, C563) was used on stained sections for mounting. controls.

Liver sections not treated with the primary antibody were used as negative

Table 1. Primary antibodies used for immunohistochemistry

\begin{tabular}{|l|l|l|}
\hline Antibodies & Source & Dilution \\
\hline \hline Desmin D33 & DAKO M0760 & $1 / 100$ \\
\hline$\alpha$-SMA 1A4 & DAKO M0851 & $1 / 50$ \\
\hline Vimentin VIM3B4 & DAKO N1583 & Ready to use \\
\hline
\end{tabular}

\section{RESULTS}

\section{Histopathology}

The microscopic examination of liver sections of dogs with expressed mild portal fibrosis showed the presence of an increased amount of connective tissue in the portal space (Figure 1). In addition, oedema was observed together with the presence of a small number of mononuclear cell elements.

Canine livers with expressed moderate portal fibrosis with mild periportal and septal fibrosis were characterized with the presence of fibrous connective tissue in the portal space which spread between hepatocytes of neighboring lobuli (Figure 2).

Canine livers with severe portal fibrosis with marked periportal and septal fibrosis or cirrhosis showed a vastly greater presence of connective tissue in comparison with the previous group (Figure 3). Connective tissue septa divide the liver parenchyma into lobuli of irregular shape and varying sizes. A chronic 
mononuclear cellular infiltrate, as well as blood vessels with hyalinized walls and a narrowed lumen are present in the connective tissue. In addition to the abundant connective tissue, cholestasis and a large number of bile ducts were observed.

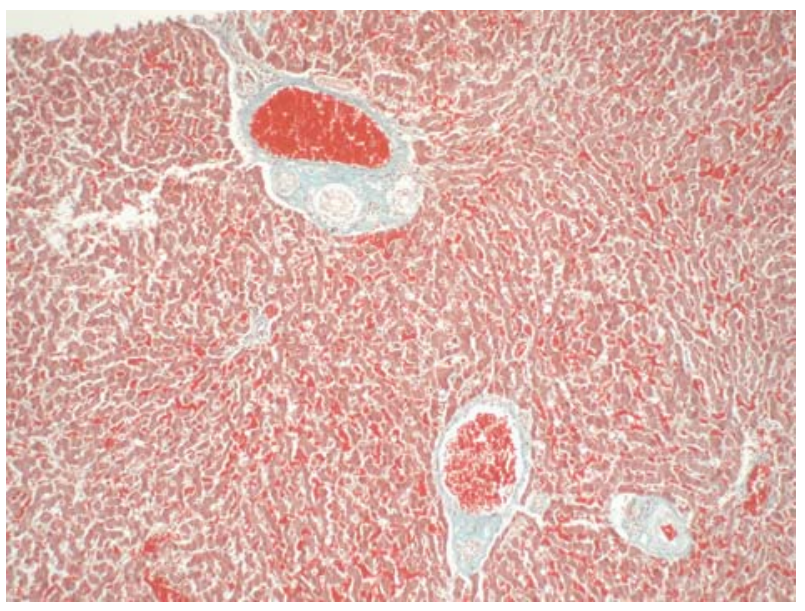

Figure 1. Canine liver with mild portal fibrosis, Masson's trichrome, 200x

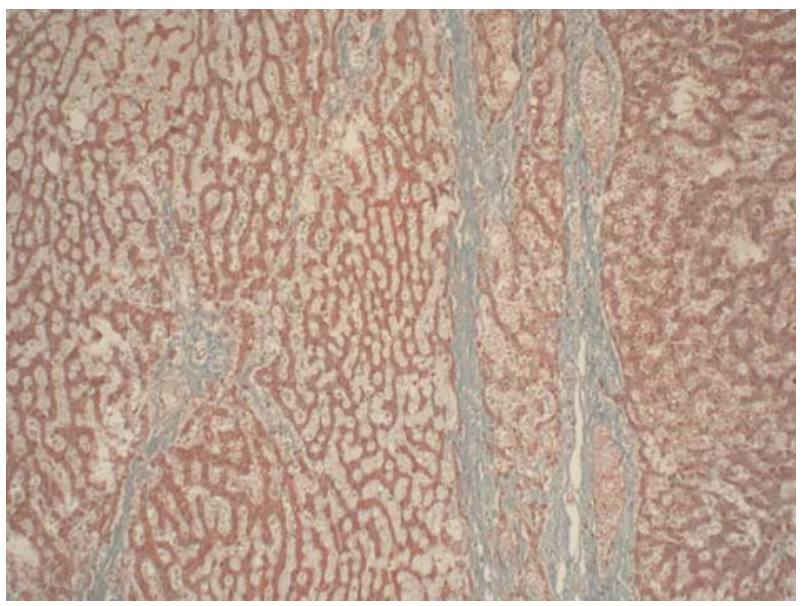

Figure 2. Canine liver with moderate portal fibrosis with mild periportal and septal fibrosis, Masson's trichrome, 200x 


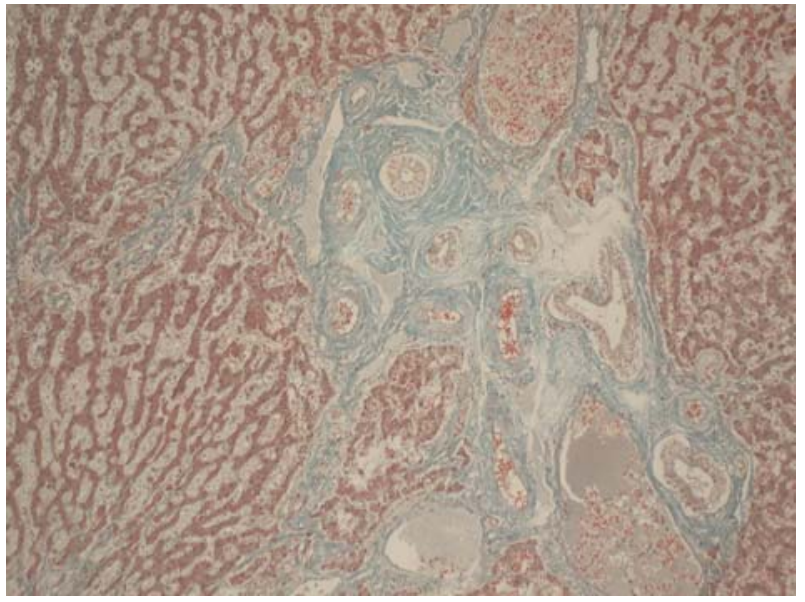

Figure 3. Canine liver with portal fibrosis with marked periportal and septal fibrosis, Masson's trichrome, 200x

\section{Imunohistochemistry}

In the sections of control canine livers, perisinusoidal HSC reacted positively to the $\alpha$-SMA antibody, diffusely, through the entire liver parenchyma. The positive reaction of pericytes and smooth muscle cells of terminal and sublobular venous blood vessels were observed. In the portal triads, a positive reaction was observed in the arterial tunica media, and a slight positivity was observed in the walls of the portal veins. Rare immunopositive cells were observed in Glisson's capsule. In the livers with fibrosis as well, immunopositivity to $\alpha$-SMA was observed on perisinusoidal HSC and their long extensions, in the form of deposits of beaded appearance. Immunopositivity to $\alpha$-SMA was observed also on the walls of blood vessels of the portal space, as well as in the increased septal connective tissue (Figure 4). Livers of dogs with moderate or severe fibrosis showed numerous $\alpha$-SMA positive cells in fibrous septs and the stroma that surrounded the regenerative lobules. With the increase in the degree of fibrosis, the degree of expression of $\alpha$-SMA also increased, both in the perisinusoidal HSC and in other localities. The intensity of the immunopositivity to the $\alpha$-SMA antibody in the portal triad was greater in dogs with fibrosis of the third degree than in the controls or all the other examined livers.

There were great variations among liver samples of control dogs in the reaction to the desmin antibody. HSC were poorly positive. In the portal area, smooth muscle cells in the tunica media of arteries and perivenular smooth muscle cells were moderately to extremely positive. A small number of spindle cells in the portal triad stroma reacted positively to the desmin antibody. In the samples of livers with fibrosis, immunoreactivity to desmin was detected in certain perisinusoidal HSC with shorter or longer extensions. In addition to these cells, round cells situated in the liver sinusoids also reacted immunopositively to 
desmin. Vascular smooth muscle cells, individual cells situated in connective tissue strips and the liver capsule were also strongly positive to desmin in livers with severe fibrosis (Figure 5). The most intensive positive reaction was found in spindle cells in the portal triad and fibrotic strips in livers of dogs with severe fibrosis and cirrhosis.

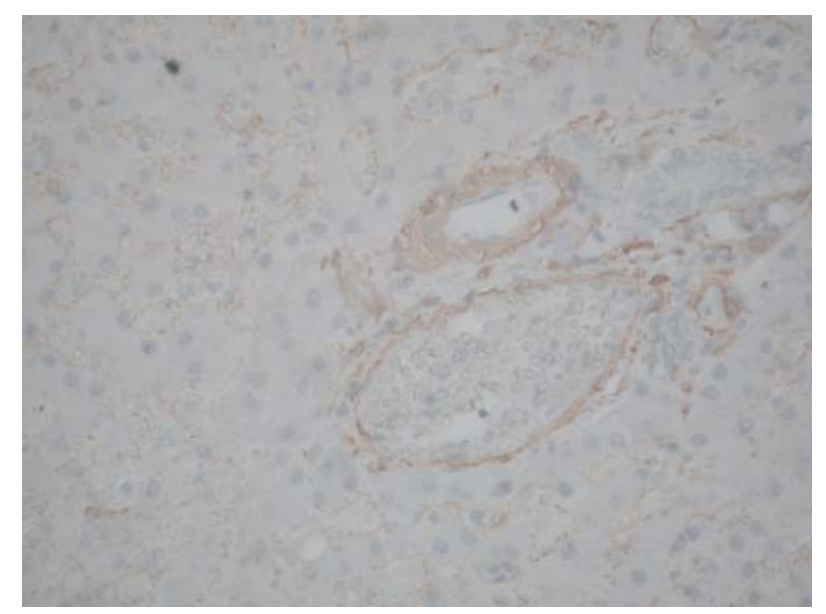

Figure 4. Canine liver $\alpha$-SMA positive cells, LSAB2, 400x

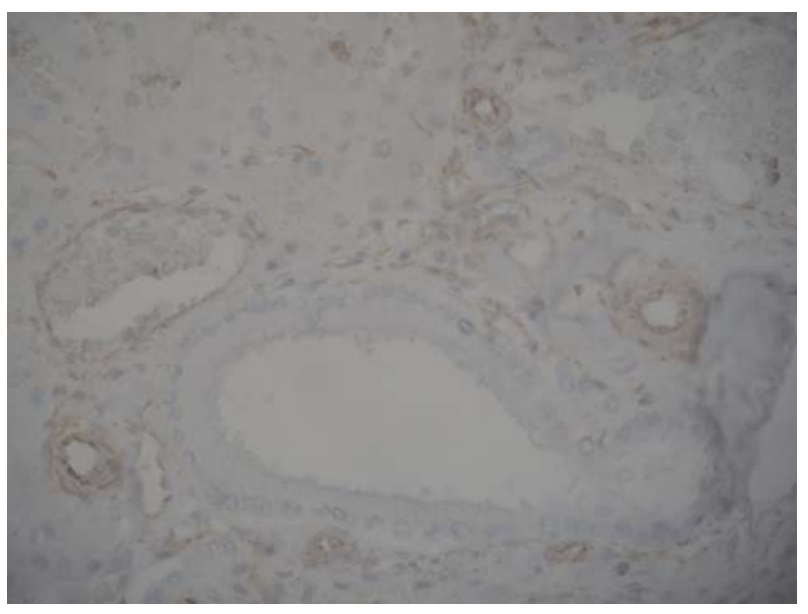

Figure 5. Canine liver desmin positive cells, LSAB2, 400x

In control livers, smooth muscle cells of blood vessels and stromal spindle cells in the portal triads reacted positive to vimentin. Perisinusoidal HSC were 
negative in the liver parenchyma, even though they reacted positive to the vimentin antibody individually. In the liver samples of dogs with fibrosis, periductal fibroblasts were positive to vimentin, as well as perisinusoidal HSC and smooth muscle cells of blood vessels (Figure 6). Vimentin-positive cells differ among each other according to shape and size and they are distributed diffusely, irregularly in perisinusoidal spaces of the liver parenchyma and portal triad. They are clearly visible in the livers of dogs with severe fibrosis and cirrhosis. Cells distributed in the fibrous septa around regenerative lobuli and the portal triad exhibited a very intense positive reaction.

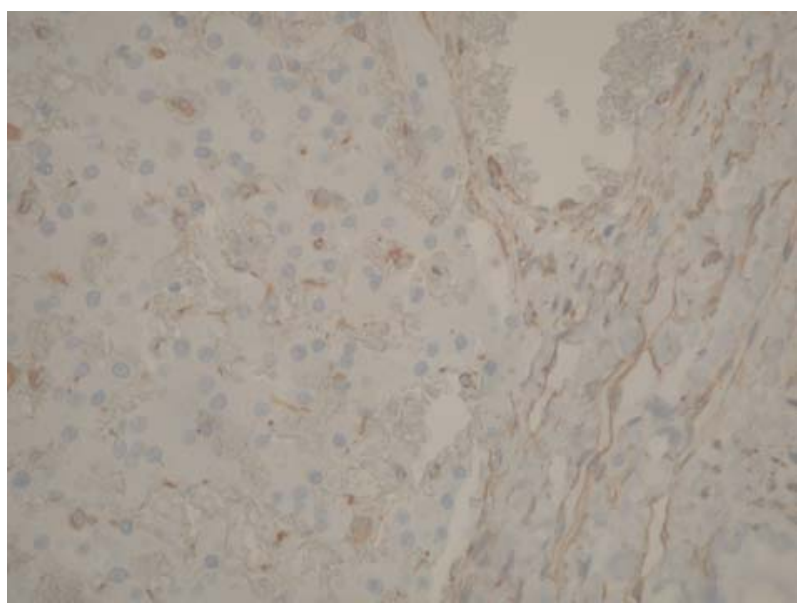

Figure 6. Canine liver vimentin positive cells, LSAB2, 400x

The absence of cells positive to all examined epitopes was observed on the periphery of regenerative lobuli that occur in liver cirrhosis.

Endothelial cells of liver blood vessels, hepatocytes and bile duct epithelium showed a negative reaction to the examined markers.

\section{DISCUSSION}

Histological and immunohistochemical examinations have contributed to a better understanding of chronic diseases of the liver in humans and rats (Mekonnen et al. , 2007; Bataller and Brener, 2005; Boisclair et al. , 2001; Friedman, 2000). Increased expression of $\alpha$-SMA in perisinusoidal HSC in areas of fibrosis around portal spaces and fibrous septa has already been reported in chronic hepatitis in humans. In the course of the development of hepatic fibrosis in humans and rats, the number of HSC increases and they differentiate into myofibroblast-like cells with significant expression of $\alpha$-SMA (Boisclair et al., 2001; Lepreux et al., 2001; Burt, 1999). Activated HSC in humans synthetize also tissue inhibitors of metalproteinases 1 and 2 that inhibit interstitial collagenase activity 
and thus contribute to the accumulation of ECM proteins (Hinz et al., 2007; Guyot et al., 2006; Bedossa and Paradis, 2003). The etiopathogenesis of chronic diseases of the liver in dogs has still not been sufficiently clarified, which is particularly true for the role of ECM proteins in the progression of hepatic fibrosis (Mekonnen et al., 2007; ljzer et al., 2006). It was observed in this work that the quantity of ECM increased in the course of liver fibrosis in dogs as a consequence of the accumulation of different proteins. This fact can be explained by the activation, migration and accumulation of HSC and myofibroblasts from other regions of the liver. Furthermore, it was shown in this study that HSC are immunoreactive to desmin, vimentin and $\alpha$-SMA. The intensity of the immunopositivity of perisinusoidal HSC to $\alpha$-SMA varied depending on the degree of fibrosis and it was strongest in the livers of dogs with cirrhosis, with the exception of hyperplastic and regenerative nodes. The absence of cells positive to $\alpha-S M A$ in hyperplastic noduli in liver cirrhosis could be a result of the absence of HSC migration during hepatic regeneration. It is known that $\alpha$-SMA is a marker for myofibroblasts, as well. The density of $\alpha$-SMA positive cells in the portal triad was in correlation with the degree of inflammation, proliferation of bile ducts and fibrosis. These results indicate that inflammation in the dog liver, as well as in the human and rat liver, is connected with the activation of periductal myofibroblasts and probably the proliferation of bile ducts (Mekonnen et al., 2007; Hinz et al., 2007; ljzer et al., 2006; Burt, 1999).

Myofibroblasts in the normal liver of dogs, or humans and rats, are located around blood vessels and bile ducts, and it was observed in this paper that their immunopositivity is increased with the degree of fibrosis. It seems that periductal myofibroblasts are important in hepatic fibrosis and when they are activated by different cytokines the synthesis and secretion of proteins of the extracellular matrix is stepped up (Guyot et al., 2006; Bedossa and Paradis, 2003). As opposed to humans and rats where the number of HSC with strong expression of $\alpha$-SMA is increased during hepatic fibrosis (Moreira, 2007; Cassiman et al., 2002; Lepreux et al., 2001; Knittel et al., 1999a,b), the expression of $\alpha$-SMA in dogs is not connected with the increased number or with the activation of HSC during fibrosis, since $\alpha$-SMA is expressed also in healthy liver tissue, as a constitutive molecule (Mekonnen et al., 2007; ljzer et al., 2006).

It is interesting to stress that it was proved in this study, in the examined liver samples, that desmin was expressed in a small population of HSC and in portal myofibroblasts. Stronger vimentin expression was evident in HSC, periductal fibroblasts and fibroblasts of the fibrose liver capsule. Normal HSC of rats express desmin and vimentin. However, activated HSC in rats also show transitory expression of nestin (Zhao and Burt, 2007).

The results obtained in this work demonstrate that perisinusoidal HSC and myofibroblasts of portal spaces participate in the development of liver fibrosis in dogs. At this point, it is not possible to determine the roles of the specific examined cellular subpopulations in different degrees of fibrosis, so that additional investigations are necessary. 


\title{
ACKNOWLEDGEMENTS:
}

This paper was supported by the Ministry of Science and Technological Development, Republic of Serbia, Project No 156010.

\author{
Address for correspondence: \\ Dr. Milijana Knežević \\ University of Belgrade \\ Faculty of Veterinary Medicine \\ Department of Pathology \\ Bulevar oslobodjenja 18 \\ 11000 Belgrade, Serbia \\ E-mail: mara@vet.bg.ac.rs
}

\section{REFERENCES}

1. Adamus C, Buggin-Daubie M, Izembart A, Sonrier-Pierre C, Guigand L, Masson T et al, 1997, Chronic hepatitis associated with leptospiral infection in vaccinated beagles, $J$ Comp Path, 117, 311-28.

2. Bataller R, Brenner DA, 2005, Liver fibrosis, J Clin Invest, 115, 209-18.

3. Bedossa P, Paradis V, 2003, Liver extracellular matrix in health and disease, J Pathol, 200, 504-15.

4. Boisclair J, Dore M, Beauchamp G, Chouinard L, Girard C, 2001, Characterization of the inflammatory infiltrate in canine chronic hepatitis, Vet Pathol, 38, 628-35.

5. Burt AD, 1999, Pathobiology of hepatic stellate cells, J Gastroenterol, 34, 299-304.

6. Cassiman D, Libbrecht L, Desmet V, Denef C, Roskams, 2002, Hepatic stellate cell/myofibroblast subpopulations in fibrotic human and rat livers, J Hepatol, 36, 200-9.

7. Center SA, 1999, Chronic liver disease: current concepts of disease mechanisms, J Small Anim Pract, 40, 106-14.

8. Friedmann S, 2000, Molecular regulation of hepatic fibrosis an integrated cellular response to tissue injury, J Biol Chem, 275, 2247-50.

9. Guyot C, Lepreux S, Combe C, Doudnikoff E, Bioulac-Sage P, Balabaud C et al, 2006, Hepatic fibrosis and cirrhosis: The (myo)fibroblastic cell subpopulations involved, Int J Bioch Cell Biol, 38, 135-51.

10. Hautekeete ML, Geerts A, 1997, The hepatic stellate (Ito) cell: its role in human liver disease, Virch Arch, 430, 195-207.

11. Hinz B, Phan SH, Thannickal VJ, Galli A, Bochaton-Piallat M, Gabbiani G, 2007, The myofibroblast: one function, multiple origins, Am J Pathol, 170, 1807-16.

12. Ide M, Yamate J, Kuwamura M, Kotani T, Sakuma S, Takeya M, 2001, Immunohistochemical analysis of macrophages and myofibroblasts appearing in hepatic and renal fibrosis of dogs, J Comp Pathol, 124, 60-9.

13. ljzer J, Roskams T, Molenbeek R, Ultee T, Penning L, Rothuizen J et al, 2006, Morphological characterisation of portal myofibroblasts and hepatic stellate cells in the normal dog liver, Comp Hepatol, 5, 7-14.

14. Knittel T, Kobold D, Piscaglia F, Saile B, Neubauer K, Mehde M et al., 1999 a, Localization of liver myofibroblasts and hepatic stellate cells in normal and diseased rat livers: distinct roles of (myo-)fibroblast subpopulations in hepatic tissue repair, Histochem Cell Biol,112, 387-401.

15. Knittel T, Kobold D, Saile B, Grundmann A, Neubauer K, $1999_{\mathrm{b}}$, Rat liver myofibroblasts and hepatic stellate cells: different cell populations of the fibroblast lineage with fibrogenic potential, Gastroenterology, 117, 1205-21.

16. Lepreux S, Dubuisson L, Lebail B, Desmouliere A, Balabaud C, Bioulac-Sage P, 2001, Can hepatic stellate cells express alpha-smooth muscle actin in normal human liver, Liver, 21, 293-4.

17. Mekonnen GA, ljzer J, Nederbragt $H$, 2007, Tenascin- $C$ in chronic canine hepatitis: Immunohistochemical localization and correlation with necro-inflammatory activity, fibrotic 
stage, and expression of alpha-smooth muscle actin, cytokeratin 7, and CD3+ cells, Vet Pathol, 44, 803-13.

18. Moreira RK, 2007, Hepatic stellate cells and liver fibrosis, Arch Pathol Lab Med, 131, 1728-34.

19. Ramadori G, Saile B, 2004, Portal tract fibrogenesis in the liver, Lab Invest, 84, 153-9.

20. Reeves HL, Friedman SL, 2002, Activation of hepatic stellate cells - a key issue in liver fibrosis, Front Biosci, 7, 808-26.

21. Safadi R, Friedman SL, 2002, Hepatic fibrosis-role of stellate cell activation, Med Gen Med, 4, 27.

22. Sato M, Suzuki S, Senoo H, 2003, Hepatic stellate cells: unique characteristics in cell biology and phenotype, Cell Struct Funct, 28, 105-12.

23. Senoo H, 2004, Structure and function of hepatic stellate cells, Med Electron Microsc, 37, 3-15.

24. Tuchweber B, Desmouliere A, Bochaton-Piallat L, Rubbia-Brandt L, Gabbiani G, 1996, Proliferation and phenotypic modulation of portal fibroblasts in the early stages of cholestatic fibrosis in the rat, Lab Invest, 74, 265-78.

25. Watson PJ, 2004, Chronic hepatitis in dogs: a review of current understanding of the aetiology, progression and treatment, Vet $J, 167,228-41$.

26. Yamate J, Ishida A, Tsujino K, Tatsumi M, Nakatsuji S, Kuwamura $M$ et al, 1996, Immunohistochemical study of rat renal interstitial fibrosis induced by repeated injection of cisplatin, with special reference to the kinetics of macrophages and myofibroblasts, Toxicol Pathol, 24, 199-206.

27. Zhao L, Burt AD, 2007, The diffuse stellate cell system, J Mol Hist, 38, 53-64.

\title{
EKSPRESIJA $\alpha$-SMA, DEZMINA I VIMENTINA U JETRI PASA SA FIBROZOM
}

\author{
KNEŽEVIĆ MILIJANA, GLEDIĆ D, KUKOLJ V, KNEŽEVIĆ DJ, JOVANOVIĆ M, \\ BOŽIĆ TATJANA i ALEKSIĆ-KOVAČEVIĆ SANJA
}

\section{SADRŽAJ}

U ovom radu su prikazani rezultati ispitivanja 36 uzoraka tkiva jetre sa znacima fibroze, poreklom od pasa. Na osnovu stepena fibroze, uzorci su klasifikovani u tri grupe: 1 - blaga portalna fibroza; 2 - umerena portalna fibroza sa blagom periportalnom i septalnom fibrozom; 3 - teška portalna fibroza sa izraženom periportalnom i septalnom fibrozom ili cirozom. Kao kontrola su korišćeni uzorci tkiva jetre dobijeni od pet pasa bez znakova infekcije, neoplazije i kardiovaskularnih bolesti. Evaluacija stepena fibroze je urađena na isečcima jetre bojenim po Masson trihromnoj metodi. Imunohistohemijskom metodom je pokazano da su HSC i periduktalni miofibroblasti imunoreaktivni na dezmin, vimentin i $\alpha$-SMA. Dezmin, vimentin i $\alpha$-SMA, pozitivne ćelije u portalnoj trijadi bile su značajno brojnije kod pasa sa fibrozom trećeg stepena u odnosu na kontrolu i na sve druge ispitivane uzorke tkiva jetre. Gustina $\alpha$-SMA, vimentin i dezmin pozitivnih ćelija u portalnoj trijadi je bila u korelaciji sa stepenom fibroze, što se ne može reći i za HSC. Ovi rezultati sugerišu da portalni miofibroblasti imaju značajnu ulogu u procesu fibroze jetre kod pasa. 